\section{Polybrominated Diphenyl Ethers in Marine Species from the Belgian North Sea and the Western Scheldt Estuary: Levels, Profiles, and Distribution}

STEFAN VOORSPOELS, *

ADRIAN COVACI, AND PAUL SCHEPENS

Toxicological Center, University of Antwerp,

Universiteitsplein 1, 2610 Wilrijk, Belgium

The Western Scheldt Estuary (SE) is subjected to a variety of suspected PBDE sources, such as a brominated flame retardant manufacturing plant, the Antwerp harbor, and the textile industry located further upstream the river. The Belgian North Sea (BNS) was included in this study to analyze the influence of the SE on the levels found in biota from the BNS locations. Benthic invertebrates, such as shrimp, crab, and starfish, benthic fish, such as goby, dab, plaice, and sole, and gadoid fish, such as bib and whiting, were sampled in the BNS (nonpolluted area) and the SE (polluted area) and analyzed to determine the concentrations and spatial variation of eight polybrominated diphenyl ethers (PBDEs 28, 47, 99, 100, 153, 154, 183, and 209). Levels found in the SE samples were up to 30 times higher than those found in BNS samples, with a gradient increasing toward Antwerp. Levels in BNS ranged from 0.02 to $1.5 \mathrm{ng} / \mathrm{g} \mathrm{ww}$ in benthic invertebrates and goby, from 0.06 to $0.94 \mathrm{ng} / \mathrm{g}$ ww in fish muscle, and from 0.84 to 128 $\mathrm{ng} / \mathrm{g}$ ww in fish liver. For the SE samples, levels ranged from 0.20 to $29.9 \mathrm{ng} / \mathrm{g}$ ww in benthic invertebrates and goby, from 0.08 to $6.9 \mathrm{ng} / \mathrm{g}$ ww in fish muscle, and from 15.0 to $984 \mathrm{ng} / \mathrm{g}$ ww in fish liver. BDE 209 could only be detected in eight liver samples from the $S E$ and levels ranged between 3.4 and $37.2 \mathrm{ng} / \mathrm{g}$ ww. PBDE profiles of the various species at the different locations were compared. Differences in profile were attributed to different exposure and to differences in metabolism among species. Ratios between BDE 99 and 100 were found to be highly location and species dependent, which could be related to differences in metabolism. Some species, such as dab, plaice bib, and whiting, showed preferential accumulation of PBDEs in the liver. Higher brominated congeners in general showed higher affinity for liver than for muscle tissue.

\section{Introduction}

Brominated flame retardants (BFRs), and especially polybrominated diphenyl ethers (PBDEs), have received increasing attention during the past years $(1-5)$. This is due to their massive use to improve fire safety in both commercial and domestic applications, where BFRs are added in concentrations up to $30 \mathrm{wt} \%$ (6). These chemicals have shown a rise

* Corresponding author phone: +3238202704 ; fax: +323820 27 22; e-mail: stefan.voorspoels@ua.ac.be in production sinee they were first introduced in the $1960 \mathrm{~s}$, with a substantial increase since the end of the 1970 s due to the growing popularity of personal computers and other electronic equipment (7). The worldwide market demand for PBDEs in 2001 was estimated to be 67390 metric tons, of which 56100 metric tons consisted of the fully brominated decabromodiphenyl ether (BDE 209) (8).

PBDEs can reach the environment through leaching during production and application processes, through volatilization and leaching during use, and through particulate losses during use and disposal (9). The current European legislation does not provide for special regulations for bromine recycling, and thus $88 \%$ of the plastics containing BFRs end up as landfill, $10 \%$ is incinerated, and only less than $3 \%$ is recycled or reused in Europe (10). This current lack of recycling of BFRs in plastics might also be held partially responsible for the increasing levels in all environmental compartments, biotic (from plankton to humans) ( 7$)$ as well as abiotic (air, water, sediments, soil) (2), since plastics account for more than half the worldwide BFR demand.

Most toxicological studies have been performed using commercial PBDEs that are mixtures of congeners and isomers, resulting in a limited amount of data about congener-specific effects (9). Acute toxicity was shown to be low in those studies, but serious health consequences, such as thyroidogenic, estrogenic, and hepatic effects, neurodevelopmental disorders, and dioxin-like activity, could result from prolonged exposure $(7,9,11,12)$. Cancer has also been described as a possible toxic effect (12).

The physicochenical properties of these compounds lead to biomagnification, as they are lipophilic and extremely resistant to degradation (13). Humans are at the top of the fond chain, which makes them very susceptible to ingestion of large quantities of these compounds through the diet (9). The toxicological aspect together with steadily increasing human and environmental levels make it likely that not only humaris but also (marine) species might experience adverse effects from these compounds (14). Aquatic organisms are especially very efficient in accumulating these compounds (15), since in addition to bioaccumulation through the diet, they are also subjected to bioconcentration.

Since benthic organisms are at the base of the marine food chain (e.g. goby, starfish, shrimp, etc.) and are also consumed by humans (e.g. crabs, shrimp, dab, sole, etc.), studies on these organisms can be used to obtain valuable information about the availability of these pollutants to higher trophic levels. Benthic organisms are known to be very sedentary, which makes them very good sentinel species. These data can therefore also be used to establish geographical trends in pollution.

In this work, various benthic species from the Belgian North Sea (BNS) and the Scheldt Estuary (SE) were analyzed for selected PBDEs. The sampling locations were chosen based on the presence of a BFR production plant at Terneuzen (The Netherlands), which is located in the SE, the high level of industrialization of the nearby harbor of Antwerp, and the textile industry further upstream the river. De Boer et al. recently reported high levels of BDE 209 (up $104600 \mathrm{ng} / \mathrm{g}$ dry weight) in suspended particulate matter (SPM) from the Western Scheldt and attribute this to spillage during use further upstream (16). Additional interest is generated by the fact that the Scheldt discharges into the North Sea, which is a very extensively exploited fishery region. Pollutants, such as PBDEs, coming from the Scheldt. will be dispersed in the narrow southern North Sea basin, where they can accumulate. The BNS was included in the study to analyze the 


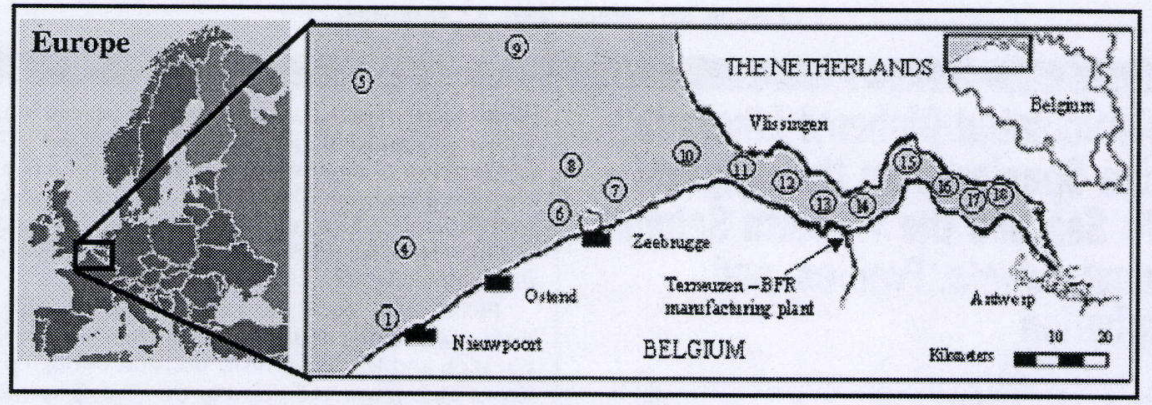

FIGURE 1. Geographical distribution of the sampling locations in BNS and SE.

\begin{tabular}{|c|c|c|c|c|c|}
\hline \multicolumn{6}{|c|}{ TABLE 1. Locations of Sampling Points } \\
\hline location & north & east & location & north & east \\
\hline $\begin{array}{l}1 \text { (BNS) } \\
4 \text { (BNS) } \\
5 \text { (BNS) } \\
6 \text { (BNS) } \\
7 \text { (BNS) } \\
8 \text { (BNS) } \\
9 \text { (BNS) } \\
10 \text { (SE) }\end{array}$ & $\begin{array}{l}51^{\circ} 09^{\prime} 88^{\prime \prime} \\
51^{\circ} 15^{\prime} 78^{\prime \prime} \\
51^{\circ} 25^{\prime} 99^{\prime \prime} \\
51^{\circ} 21^{\prime} 48^{\prime \prime} \\
51^{\circ} 22^{\prime} 89^{\prime \prime} \\
51^{\circ} 27^{\prime} 01^{\prime \prime} \\
51^{\circ} 32^{\prime} 64^{\prime \prime} \\
51^{\circ} 26^{\prime} 70^{\prime \prime}\end{array}$ & $\begin{array}{l}2^{\circ} 3787^{\prime \prime} \\
2^{\circ} 35^{\prime} 17^{\prime \prime} \\
2^{\circ} 31^{\prime} 01^{\prime \prime} \\
3^{\circ} 07^{\prime} 58^{\prime \prime} \\
3^{\circ} 1491^{\prime \prime} \\
3^{\circ} 10^{\prime} 18^{\prime \prime} \\
2^{\circ} 53^{\prime} 34^{\prime \prime} \\
3^{\circ} 26^{\prime} 36^{\prime \prime}\end{array}$ & $\begin{array}{l}11 \text { (SE) } \\
12 \text { (SE) } \\
13 \text { (SE) } \\
14 \text { (SE) } \\
15 \text { (SE) } \\
16 \text { (SE) } \\
17 \text { (SE) } \\
18 \text { (SE) }\end{array}$ & $\begin{array}{l}51^{\circ} 25^{\prime} 19^{\prime \prime} \\
51^{\circ} 24^{\prime} 29^{\prime \prime} \\
51^{\circ} 21^{\prime} 41^{\prime \prime} \\
51^{\circ} 20^{\prime} 55^{\prime \prime} \\
51^{\circ} 25^{\prime} 78^{\prime \prime} \\
51^{\circ} 23^{\prime} 32^{\prime \prime} \\
51^{\circ} 22^{\prime} 53^{\prime \prime} \\
51^{\circ} 23^{\prime} 21^{\prime \prime}\end{array}$ & $\begin{array}{l}3^{\circ} 36^{\prime} 91^{\prime \prime} \\
3^{\circ} 41^{\prime} 41^{\prime \prime} \\
3^{\circ} 46^{\prime} 22^{\prime \prime} \\
3^{\circ} 51^{\prime} 29^{\prime \prime} \\
4^{\circ} 01^{\prime} 32^{\prime \prime} \\
4^{\circ} 03^{\prime} 25^{\prime \prime} \\
4^{\circ} 05^{\prime} 19^{\prime \prime} \\
4^{\circ} 10^{\prime} 53^{\prime \prime}\end{array}$ \\
\hline
\end{tabular}

TABLE 2. Overview of Sampled Species

class

species name

Benthic invertebrates Crangon crangon (common shrimp) Asterias rubens (red starfish) Lyocarcinus holsatus (flying crab)

Benthic fish

Benthic flatfish

Pomatoschistus minutus (sand goby)

Solea solea (common sole) -

Limanda limanda (dab)-

Pleuronectus platessa (plaice)

Gadoid fish

Merlangius merlangus (whiting) -

Trisopterus luscus (bib)

influence of the SE on the levels found at the differen locations. The data presented in this study are complementary to a recently published study by Boon et al., which covers the PBDE pollution in similar marine species from the Northern part of the North Sea and the Tees estuary, U.K. (17).

Such detailed PBDE data about this region, which is characterized by possible point sources, and which includes benthic invertebrates and different fish species from both polluted (SE) and nonpolluted (BNS) areas, has not been published to date, according to our knowledge.

\section{Experimental Section}

Sampling. Seven locations were selected in the BNS and nine locations in the Scheldt Estuary (SE) (Figure 1 and Table 1). Selection of the species was based upon their occurrence in space and time at the sampling locations. Three species of benthic invertebrate organisms were chosen. These organisms are very suitable as sentinel species, since they tend not to migrate. Crab species have also been extensively used as sentinel organism in monitoring studies of lipophilic contaminants on Canada's West Coast (3). Three flatish species and two gadoid fish species were also sampled at the same locations. An overview of all sampled species is presented in Table 2.

The number of individuals caught was different for each location and varied between 3 and 10 for starfish, between 30 and 50 for shrimp, crab, and goby, and between 1 and 5 for the other fish species. Sampling campaigns took place during October and November 2001. All organisms were collected with a $3 \mathrm{~m}$ beam trawl with fine-meshed nets $(6 \times$ $6 \mathrm{~mm}$ ), at a constant speed of $1.5-2.0$ knots for about 30 min., using the research vessel Zeeleeuw, provided by the Flemish Marine Institute (VLIZ).

Preliminary sample pretreatment steps were undertaken on board, and they included species determination, recordin of fish length, and washing with clean water. Prior to storage in hexane prewashed glass recipients at $-20^{\circ} \mathrm{C}$, the flatfishes and gadoids were dissected on board immediately after capture, and only the excised muscle and liver samples were collected. For the invertebrates and goby samples, the entire animals were stored.

Sample Availability. All sampled species were available in large amounts for the BNS locations, unlike for the SE. Crab and shrimp were very abundant and thus available for each location of the BNS and SE. For starfish and goby species, samples could only be taken at one and two locations in the $\mathrm{SE}$, respectively. Dab was also difficult to catch in great quantities for SE locations, resulting in only one pooled sample at one location in the SE. Other flatfish and gadoids were caught in at least five locations on the BNS and three locations in the SE.

Targeted Compounds. Based on reported abundance (11, $18-21$ ) and toxicity (2), the following BDE-congeners (IUPAC numbering) were targeted for analysis: $28\left(2,4,4^{\prime}-\right.$ triBDE), $47\left(2,2^{\prime}, 4,4^{\prime}\right.$-tetraBDE $), 99\left(2,2^{\prime}, 4,4^{\prime}, 5\right.$-pentaBDE $), 100\left(2,2^{\prime}, 4,4^{\prime}, 6\right.$ pentaBDE), $153\left(2,2^{\prime}, 4,4^{\prime}, 5,5^{\prime}\right.$-hexaBDE), $154\left(2,2^{\prime}, 4,4^{\prime}, 5,6^{\prime}-\right.$ hexaBDE), $183\left(2,2^{\prime}, 3^{\prime}, 4,4^{\prime}, 5,6^{\prime}\right.$-heptaBDE), and $209\left(2,2^{\prime}, 3,3^{\prime}, 4,4^{\prime}\right.$, $5,5^{\prime}, 6,6^{\prime}$-decaBDE). Polybrominated biphenyl (PBB) 103 was used as internal standard (IS) for BDE 28 to 183 . For BDE $209,{ }^{13} \mathrm{C}-\mathrm{BDE} 209$ was used as IS.

Chemicals. All solvents used for the analysis ( $n$-hexane, acetone, isooctane) were of SupraSolv grade (Merck, Darmstadt, Germany). Individual reference standards for each of the eight BDE congeners were used for identification and quantification (CIL, Andover, U.S.A). Sodium sulfate was heated at least $6 \mathrm{~h}$ at $600^{\circ} \mathrm{C}$, and silica was prewashed with n-hexane before use. Extraction thimbles were pre-extracted for $1 \mathrm{~h}$ with the extraction mixture used for the samples and dried at $100^{\circ} \mathrm{C}$ for $1 \mathrm{~h}$.

Sample Preparation and Cleanup. Prior to analysis, the samples were defrosted and homogenized, using a highspeed blade-mixing device, except for the shrimp and crab samples, of which only the soft parts were taken. After homogenization, two identical composite samples of each species, location, and tissue were created. Thirty individuals were homogenized for shrimp, goby, and crab samples since these organisms were readily available in large amounts. For starfish samples the pools consisted of $3-8$ equally sized individuals. For the fish samples, fish size was taken into account when samples were pooled and the median length 
was recorded. Pools of gadoids and flatfish consisted of $3-6$ individuals. The only exceptions were pools that consisted only of 1 or 2 individuals for dab from location 14 , and for sole from locations 15 and 16 , respectively.

The method used for the clean up of the samples has been previously described and validated (22) and is briefly presented below. Between 1 and $10 \mathrm{~g}$ of homogenized sample was dried with approximately $15 \mathrm{~g}$ anhydrous sodium sulfate, spiked with internal standards PBB 103 and ${ }^{13} \mathrm{C}-\mathrm{BDE} 209$ (between 1 and $20 \mathrm{ng}$, depending on the pollution load of the sample) and extracted for $2.5 \mathrm{~h}$ by hot Soxhlet with 100 $\mathrm{mL}$ of hexane/acetone $(3 / 1 ; \mathrm{v} / \mathrm{v})$. After lipid determination (performed on an aliquot of the extract), the extract was cleaned-up on $8 \mathrm{~g}$ of acidified silica. After elution with $15 \mathrm{~mL}$ of hexane, the cleaned extract was concentrated to approximately $80 \mu \mathrm{L}$.

Chemical Analysis. All analyses were performed using a Hewlett-Packard 6890 GC (Palo Alto, U.S.A.) connected via direct interface with a HP 5973 mass spectrometer. PBDE congeners $28,47,99,100,153,154$, and 183 in crab, goby, starfish, and fish muscle samples were analyzed with a $10 \mathrm{~m}$ $\times 0.1 \mathrm{~mm} \times 0.1 \mu \mathrm{m}$ HT-8 (nartow bore) capillary column (SGE, Belgium). Due to residual lipids in the extract (e.g. cholesterol), combined with low column capacity of the 10 $\mathrm{m}$ narrow bore column, a $25 \mathrm{~m} \times 0.22 \mathrm{~mm} \times 0.25 \mu \mathrm{m}$ HT- 8 capillary column (SGE, Belgium) was used to analyze these congeners in shrimp and fish liver samples. The carrier gas was helium, and the flow rate was held constant at 0.4 and $1.0 \mathrm{~mL} / \mathrm{min}$, for the 10 and $25 \mathrm{~m}$ column, respectively. The oven temperature program for the $10 \mathrm{~m}$ narrow bore column was starting from $90^{\circ} \mathrm{C}$, kept for $1.5 \mathrm{~min}$, then with $40^{\circ} \mathrm{C} /$ min to $220^{\circ} \mathrm{C}$, held $0.5 \mathrm{~min}$, with $25^{\circ} \mathrm{C} / \mathrm{min}$ to $300^{\circ} \mathrm{C}$, and held $6 \mathrm{~min}$. For the $25 \mathrm{~m}$ column, the temperature program was starting from $90^{\circ} \mathrm{C}$, kept for $1.5 \mathrm{~min}$, then with $30^{\circ} \mathrm{C} /$ min to $180^{\circ} \mathrm{C}$, held $0.5 \mathrm{~min}$, with $5^{\circ} \mathrm{C} / \mathrm{min}$ to $270^{\circ} \mathrm{C}$, held $0.5 \mathrm{~min}$, and further with $25^{\circ} \mathrm{C} / \mathrm{min}$ to $290^{\circ} \mathrm{C}$, and held 15 $\min$.

One microliter of the final cleaned extract was injected into a programmable temperature vaporizer (PTV). The injector was operated in splitless mode for the narrow bore column (injector temperature: $90^{\circ} \mathrm{C}$, held for $0.05 \mathrm{~min}$, then with $700^{\circ} \mathrm{C} / \mathrm{min}$ to $290^{\circ} \mathrm{C}$, and kept for $7 \mathrm{~min}$; the purge vent. opened at $1.5 \mathrm{~min}$ ). Solvent vent mode was used for the 25 m column (injector temperature: $90^{\circ} \mathrm{C}$, held for $0.05 \mathrm{~min}$, then with $700^{\circ} \mathrm{C} / \mathrm{min}$ to $280^{\circ} \mathrm{C}$, and kept for $25 \mathrm{~min}$; vent flow was set at $100 \mathrm{~mL} / \mathrm{min}$ and the purge vent opened at $1.5 \mathrm{~min})$.

The mass spectrometer was operated in electron capture negative ionization (ECNI) in the selected ion-monitoring (SIM) mode at the $\mathrm{m} / \mathrm{z}=79$ and 81 .

For the analysis of BDE 209 , a $15 \mathrm{~m} \times 0.18 \mathrm{~mm} \times 0.10 \mu \mathrm{m}$ AT-5 (Alltech, Lokeren, Belgium) capillary column was used. Helium was used as carrier gas at a constant flow rate of 2.0 $\mathrm{mL} / \mathrm{min}$. The oven temperature program was starting from $90^{\circ} \mathrm{C}$, kept for $1.35 \mathrm{~min}$, then with $75^{\circ} \mathrm{C} / \mathrm{min}$ to $305^{\circ} \mathrm{C}$, and was held for $7.50 \mathrm{~min}$. One microliter of the final cleaned extract was injected into a PTV. The injector was operated in solvent vent mode (injector temperature: $90^{\circ} \mathrm{C}$, held for $0.06 \mathrm{~min}$, then with $700^{\circ} \mathrm{C} / \mathrm{min}$ to $310^{\circ} \mathrm{C}$, and kept for 12 min). The mass spectrometer was operated in ECNI in SIM mode at the $\mathrm{m} / \mathrm{z}$ ratios of $484.7 / 486.7$ and $494.7 / 496.7$ for BDE 209 and ${ }^{13} \mathrm{C}-\mathrm{BDE} 209$, respectively.

For all columns, methane was used as moderating gas, and the ion source, quadrupole, and interface temperatures were 250,150 , and $300^{\circ} \mathrm{C}$, respectively. Dwell times were set at 10 and 30 for PBDE analysis on the 10 and $25 \mathrm{~m}$ column, respectively, and $100 \mathrm{~ms}$ for the analysis of BDF 209.

Quality Assurance. The quality control was done by regular analyses of procedural blanks, solvent blanks, spiked samples, blind duplicate samples, in-house reference mate- rial, and injection of standards. The two pools that were created for each species, tissue, and location were treated as separate samples. Results for two identical pools did not differ more than $10 \%$, and thus the mean value of the two analyses was taken for further calculations. Analyte identification was based on retention times and peak shape. Recoveries for individual PBDE congeners were established to be between 87 and $104 \%$ ( $R S D \leq 12 \%$ ). No recovery differences were found between different spiking levels $(0.1$ $\mathrm{ng} / \mathrm{g}, 1.0 \mathrm{ng} / \mathrm{g}$, and $5.0 \mathrm{ng} / \mathrm{g}$ ). Four overlapping 5-point narrow range calibration curves were used to quantify the wide range of sample concentrations found.

Limit of detection (LOD), defined as 3 times the noise level, and limit of quantification (LOQ), based on GC-MS performance, were established at $0.1 \mathrm{pg} / \mu \mathrm{L}$ and $0.8 \mathrm{pg} / \mu \mathrm{L}$ extract injected, respectively, for BDE $28,47,99,100,153$, 154 , and 183. Sample intake was adapted to the pollution load of each sample, resulting in LOQs between 0.01 and $0.08 \mathrm{ng} / \mathrm{g} \mathrm{ww}$ for these congeners. Procedural blank values were found to be consistent (RSD $<10 \%$ ), and therefore the mean procedural blank value was used for subtraction. Results are reported as "not detected" (ND) when the concentration is lower than $0.01 \mathrm{ng} / \mathrm{g} w \mathrm{w}$. LOD and LOQ for BDE 209, established in the same manner, were 0.08 and 0.8 $\mathrm{ng} / \mathrm{g}$ ww, respectively. Due to relatively high (mean $=0.66$ ng/extraction) but consistent (RSD < 30\%) procedural blank values for the BDE 209 analyses, mean procedural blank values have been subtracted from the results, and results are only reported if the blank corrected values are higher than 3 times the mean blank value, i.e., reported values are at least 4 times higher than the mean procedural blank. A generally applicable $\mathrm{LOQ}$ per gram sample could not be calculated due to different sample intakes related to availability for each sample, but LOQs for the positive samples ranged between 2 and $4 \mathrm{ng} / \mathrm{g}$ ww.

No cerlified reference materials are currently available for PBDEs in biota. The participation of the Toxicological Center in the recent interlaboratory studies for PBDEs showed a very good performance $(23,24)$, which was repeated in the $\mathrm{BROC}$ certification feasibility study, which was organized in 2002-2003 (25)

Statistical Analysis. A number of statistical tests were applied to address all the specific needs of this study. For samples with concentrations below detection limits, which were minor in number, zero was used for the calculations. Simple linear regression cuefficient was used to test for correlations between the lipid content and the contaminant load and between the total PBDE load and the distance to Antwerp. Correlations between fish size and contaminant load and between fish size and lipid content were tested with the Kruskal-Wallis test. To compare the mean concentrations in BNS and SE and to compare accumulation factors between species, the Mann Whimey U-test was used. This test was also used to test the differences between PBDE profiles found in liver and muscle and to test differences in the ratio between BDE 99 and 100 in BNS and SE samples. Wilcoxon matched pairs signed rank test was used to compare the levels in muscle and liver, to compare liver accumulation factor for lower brominated congeners with higher brominated congeners. To compare PBDE profiles between species and locations, an unpaired $t$-test for equal variances was used. Unless stated differendy, significance levels for all tests were $p=0.05$. All statistical tests were performed using Statistica v5.0 software (StatSoft Inc., Tulsa, U.S.A.).

\section{Results and Discussion}

Lipid Content. A lipid determination on a separate sample aliquot was not performed because of the low sample amount for some locations, species, or lissues. Instead the lipid determination was performed on an aliquot of the extract 


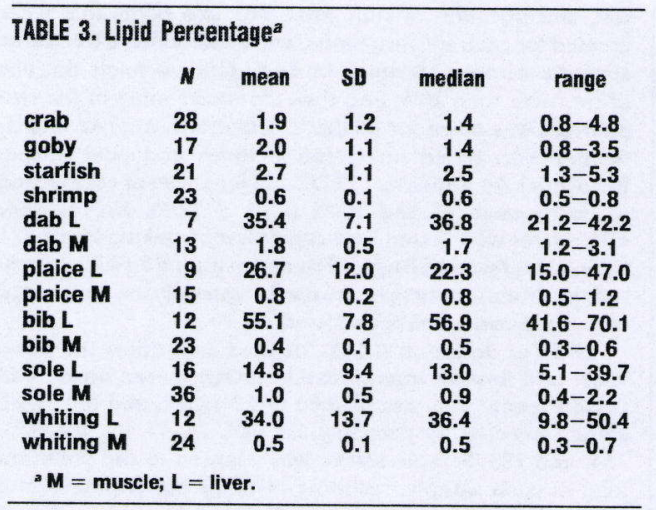

(1/5th) before clean up. Good lipid recoveries for lean and fatty fish were obtained using our method during QUASIMEME interlaboratory exercises. The basic statistical data of the lipid determinations are shown in Table 3.

The lipid percentage of fish tissue can be influenced by several factors, such as sex, age, and species (26). Additionally, an annual cycle in lipid composition, which is related to the fish' nourishment and spawning status, can be observed, with higher lipid percentages in the prespawning period (27) and during plankton bloom periods (28). This may well affect lipid normalized data presentation, especially in females. since they can dispose of their contaminants during spawning by incorporating large amounts of fat and persistent pollutants in the roe (26). In the same study of Larsson et al., male pike showed higher levels of contaminants than females, because elimination in milt is less than in roe (26). Moreover, the method used to perform the lipid determination greatly influences the result (17), which can introduce substantial errors for lean fishes when results are normalized to lipid weight.

A study in female pike (Esox lucius) showed a significant negative correlation between age and levels of the lipophilic contaminants polychlorinated biphenyls (PCBs) and 2,2-bis(4-chlorophenyl)-1,1-dichloroethylene (p,p'-DDE), which could be explained by yearly elimination of contaminants during spawning (26). These effects of spawning on con- taminant load are very species dependent, since some species are sexually mature at a very old age (e.g., lake trout), while others only spawn every 3 years or die after spawning (e.g. salmonids) (26). Samples in this study were all taken prior to spawning, meaning all lipid percentages are near a theoretical maximum.

Detected PBDE Congeners and Levels. BDE 47 and 100 were found to be the only two congeners present in every sample analyzed. BDE 183 could not be detected in any sample. In the samples from the BNS, PBDE congeners 28 , 99,154 , and 153 could be detected in $79 \%, 83 \%, 90 \%$, and $71 \%$ of the samples, respectively. All congeners could be detected in the samples from the SE, except BDE $28(96 \%)$ and BDE $153(94 \%)$ (Tables SI-1, SI-2, and SI-3). Sum of BDEs refers to the sum of the six consistently detected congeners, namely BDE $28,47,99,100,153$, and 154 (Table 4). BDE 49 was detected in all samples from the SE but not quantified due to the lack of a suitable standard. Polybrominated biphenyl (PBB) 153, which is eluting between BDE 154 and BDE 153 on the HT- 8 column, could not be detected in any sample.

The fact that BDE 183 was never detected does not mean that it is not present or that it is not bioavailable. A study of sediments taken from the same locations as the biota samples in this study will give a definitive answer whether this congener is present or not. Results of these analyses are being processed and will be published soon. Following a carp feeding study, Stapleton et al. stated that BDE 183 is not accumulated in carp tissues but is debrominated in the intestine to BDE 154, which does accumulate (29).

BDE 209 could be detected in eight pooled liver samples ( 1 sole, $3 \mathrm{bib}$, and 4 whiting samples). Due to relatively high but consistent procedural blank values for this congener, special measures have been taken to exclude any false positive results, as described in the section Quality Assurance. Levels of BDE 209 ranged between 3.4 (LOQ $=2.8)$ and $37.2 \mathrm{ng} / \mathrm{g}$ $W W(L O Q=3.5)$. The latter was found in a bib sample from the SE. A typical chromatogram of both a method blank and a sample is presented in Figure 2.

These low levels, but significantly higher than procedural blanks, of BDE 209 in liver samples are probably related to very recent exposure. Due to a possible very low half-life time of this congener, a very rapid decrease in tissue levels may be observed. Elimination of higher brominated PBDEs occurs more rapidly and half-life times of 7 days have been

\begin{tabular}{|c|c|c|c|c|c|c|c|c|c|c|c|c|c|c|}
\hline location & shrimp & crab & starfish & goby & $\begin{array}{l}\text { dab } \\
\text { liver }\end{array}$ & $\begin{array}{l}\text { dab } \\
\text { muscle }\end{array}$ & $\begin{array}{l}\text { plaice } \\
\text { liver }\end{array}$ & $\begin{array}{l}\text { plaice } \\
\text { muscle }\end{array}$ & $\begin{array}{l}\text { bib } \\
\text { liver }\end{array}$ & $\begin{array}{l}\text { bib } \\
\text { muscie }\end{array}$ & $\begin{array}{l}\text { sole } \\
\text { liver }\end{array}$ & $\begin{array}{c}\text { sole } \\
\text { muscle }\end{array}$ & $\begin{array}{l}\text { whiting } \\
\text { liver }\end{array}$ & $\begin{array}{l}\text { whiting } \\
\text { muscle }\end{array}$ \\
\hline \multicolumn{15}{|c|}{ BNS $^{b}$} \\
\hline 1 & 0.02 & 0.92 & 0.14 & 0.42 & 6.9 & 0.26 & 5.2 & 0.32 & 71.6 & 0.28 & 4.8 & 0.33 & 24.1 & 0.14 \\
\hline 4 & a & 0.85 & 0.26 & $a$ & 7.1 & 0.25 & 3.8 & 0.06 & $a$ & $a$ & $a$ & $a$ & 19.7 & 0.22 \\
\hline 5 & $a$ & 0.36 & 0.14 & $a$ & 2.8 & 0.15 & $a$ & $a$ & $a$ & $a$ & 1.2 & 0.08 & $a$ & $a$ \\
\hline 6 & 0.08 & 1.4 & 1.5 & 1.8 & a & $a$ & $a$ & $a$ & 108 & 0.22 & 8.2 & 0.40 & 89.1 & 0.92 \\
\hline 7 & 0.04 & 1.0 & 1.2 & 0.80 & $a$ & $a$ & a & 0.44 & 97.2 & 0.38 & 0.84 & 0.73 & 89.9 & 0.53 \\
\hline 8 & 0.03 & 0.62 & 0.98 & 1.1 & 6.0 & 0.40 & 37.9 & 0.94 & 27.8 & 0.76 & 2.6 & 0.55 & 24.5 & 0.44 \\
\hline 9 & 0.03 & 1.2 & 0.59 & 0.16 & 12.0 & 0.39 & 3.1 & 0.09 & $a$ & $a$ & 1.0 & 0.10 & a & $a$ \\
\hline \multicolumn{15}{|c|}{$\mathbf{S E}^{c}$} \\
\hline 10 & 0.20 & 1.2 & 2.5 & 3.9 & $a$ & $a$ & $a$ & $a$ & 248 & 0.86 & $a$ & $a$ & 75.2 & 1.0 \\
\hline 11 & 0.27 & 14.1 & $a$ & $a$ & $a$ & $a$ & $a$ & $a$ & 206 & 0.78 & 15.0 & 0.08 & & $a$ \\
\hline 12 & $a$ & 10.0 & $a$ & $a$ & $a$ & $a$ & $a$ & $a$ & 174 & 0.88 & $a$ & $a$ & $a$ & $\bar{a}$ \\
\hline 13 & 0.70 & 12.8 & 15.5 & $a$ & $a$ & $a$ & 94.3 & $a$ & 639 & 2.2 & 46.8 & 6.5 & a & $a$ \\
\hline 14 & 0.83 & 27.9 & $a$ & 9.7 & 18.6 & 0.66 & 304 & 6.1 & 537 & 1.9 & 44.5 & 5.1 & 393 & 2.4 \\
\hline 15 & 2.3 & 13.6 & $a$ & $a$ & $a$ & $a$ & $a$ & $a$ & 984 & 5.6 & 37.7 & 6.3 & 279 & 1.0 \\
\hline 16 & 8.3 & 29.9 & $a$ & $a$ & $a$ & $a$ & 74.4 & $a$ & $a$ & $a$ & 90.1 & 6.9 & 236 & 3.0 \\
\hline 17 & 7.6 & $a$ & $a$ & $a$ & $a$ & $a$ & $a$ & $a$ & $a$ & $a$ & 93.3 & 5.3 & $a$ & $a$ \\
\hline 18 & 7.6 & $a$ & $a$ & $a$ & $a$ & $a$ & $a$ & $a$ & $a$ & $a$ & $a$ & $a$ & $a$ & $a$ \\
\hline \multicolumn{15}{|c|}{${ }^{3}$ Not available. ${ }^{b}$ BNS $=$ Belgian North Sea. ${ }^{c}$ SE $=$ Scheldt Estuary. } \\
\hline
\end{tabular}




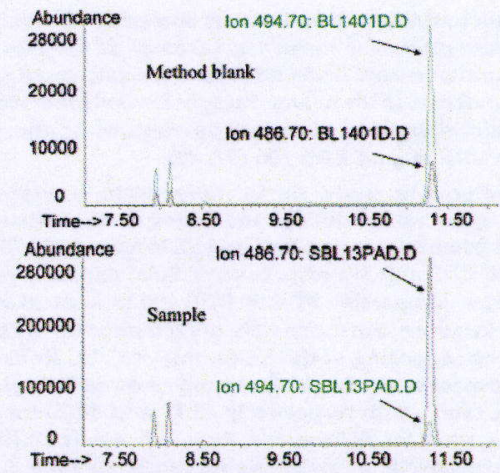

FICURE 2. GC-ECNI chromatogram of a BDE 209 analysis from a procedural blank and from a sample $(37.2 \mathrm{ng} / \mathrm{g} \mathrm{ww})$. Equal amounts of internal standard ( ${ }^{13} \mathrm{C}$-BDE 209 ) have been added for both analyses (3.75 ng), lon $m / 2486.7$ is used to quantify BDE 209; ion $m / 2494.7$ is used to quantify ${ }^{13} \mathrm{C}-\mathrm{BDE} 209$.

calculated for BDE 209 in humans (30). Sampling time may become thus very critical in finding BDE 209 in marine biota.

BDE 209 is of special interest because it is believed to be nonbioavailable and to be a virtually harmless compound (18). Few studies are published demonstrating that aquatic biota are able to accumulate BDE 209 (31). Kierkegaard et al. showed that BDE 209 can be taken up by rainbow trout (Oncorhynchus mykiss) in laboratory experiments and that liver was the main target organ (32). The first report of BDE 209 being accumulated by freshwater bream in the environment was only recently reported by Lepom et al. (31), with concentrations up to $37 \mathrm{ng} / \mathrm{g} \mathrm{lw}$. In terrestrial life, Sellström et al. has found BDE 209 in eggs of the top predator peregrine falcon (Falco peregrinus) in relatively high concentrations (33). This implicates that the birds were able to accumulate the compound and to pass it on to the eggs without prior modification or metabolization. BDE 209 presence in humans working in a recycling factory of electronic household equipment has also been demonstrated (34). These findings are of great importance since they show that the assumption that BDE 209 is not bioavailable is not correct. The present study could not clearly confirm the possible bioavailability of BDE 209 , but eight samples showed detectable levels above LOQ for this congener. But even if BDE 209 is not taken up. degradation products, i.e., lower brominated BDEs, may still accumulate. However, the degradation pathways of BDE 209 are however poorly understood $(7,32)$.

For each species, levels of PBDEs were statistically higher for all SE locations when compared to the BNS locations, while the lipid percentages for each species were similar for the two areas. This indicates a pollution source in or near the SE. Levels in BNS ranged from 0.02 to $1.5 \mathrm{ng} / \mathrm{g} \mathrm{ww}$ in benthic invertebrates and goby, from 0.06 to $0.94 \mathrm{ng} / \mathrm{g}$ ww in fish muscle, and from 0.84 to $128 \mathrm{ng} / \mathrm{g}$ ww in fish liver, respectively. For the SE samples, levels ranged from 0.20 to $29.9 \mathrm{ng} / \mathrm{g}$ ww in benthic invertebrates and goby, from 0.08 to $6.9 \mathrm{ng} / \mathrm{g}$ ww in fish muscle, and from 15.0 to $984 \mathrm{ng} / \mathrm{g} \mathrm{ww}$ in fish liver.

Special attention should be attributed to crab and starfish since levels found in these organisms are significantly higher than the levels found in shrimps. This can be ascribed to their dynamic position in the food web; crabs and starfish are scavengers that also feed on higher organisms once these have died and have dropped to the sea floor (35).

PBDE Levels in Fish from Other Studies. Comparison of levels from different studies can be done by using IPBDEs or by using individual congeners. The former can have a few drawbacks since the congeners included might vary. Using separate congeners, such as BDE 47 , which is most abundant in the marine environment (2), can therefore be a solution and will be applied here (17).

To be able to compare data with other studies, levels were recalculated to lipid-based results. In the present study, BDE 47 levels ranged from 3 to $108 \mathrm{ng} / \mathrm{g} / \mathrm{w}$ in species from the BNS, while levels from 8 to $1548 \mathrm{ng} / \mathrm{g}$ lw were observed for the SE. A recent study from Boon et al. (17) which also included starlish, crab, and whiting, and focused on the northern part of the North Sea, showed comparable levels of PBDEs as the BNS locations in the present study. Comparable BDE 47 levels to the ones found for starish from the $S E$ in the present study $(603 \mathrm{ng} / \mathrm{g} \mathrm{lw})$, were also found by Boon et al. in starlish from the polluted Tees estuary with maximum BDE 47 levels of $546 \mathrm{ng} / \mathrm{g}$ lw (17).

Although the highly polluted Scheldt discharges into the BNS, this does not seem to influence the levels found in biota of that area, since levels of the BNS are comparable to those found in the northern part of the North Sea (17).

Similar values as from the BNS samples have been reported for the northern Allantic Sea, with levels of BDE 47 up to $8 \mathrm{ng} / \mathrm{g}$ lw for salmon (Salmo salar) (36), while for the Baltic Sea $46 \mathrm{ng} / \mathrm{g} / \mathrm{w}(36)$ and $110 \mathrm{ng} / \mathrm{g} \mathrm{lw}$ (37) were observed. For fish from southern Greenland, BDE 47 levels up to 41 $\mathrm{ng} / \mathrm{g}$ lw were reported, which is comparable to the lower values found in the BNS (37). Reported values in flounder liver from locations near the Dutch coastline were comparable with the levels found in the present study for the BNS, whereas BDE 47 levels from the Rotterdam harbor area were as high as $280 \mathrm{ng} / \mathrm{g} \mathrm{lw}$, which is comparable to the lower levels in the SE (38).

Several studies have reported levels of the same order of magnitude as those found in the SE samples, with concentrations over $1000 \mathrm{ng} / \mathrm{g}$ lw in Virginia freshwater fish, which were probably related to textile manufacturing (15). Asplund et al. reported values of $1700 \mathrm{ng} / \mathrm{g}$ lw for steelhead trout (Oncorhynchus mykiss) from Lake Michigan (39), while for biota living downstream possible sources in the UK (Tees bay), values up to $9500 \mathrm{ng} / \mathrm{g}$ lw were reported in flounder liver (18).

Concentrations found in this study are higher than those reported in most other studies, which clearly suggests a source in or near the Scheldt. The presence of a bromine plant and the fact that the upstream area is home to significant textile manufacturing might suggest that these can be contributing factors to the high levels of PBDEs found in the SE.

Observed Profiles. BDE 47 was the most abundant analyte in all analyzed samples with a contribution ranging between 43 and $75 \%$. The general order of decreasing contribution to the total load is BDE $47>\mathrm{BDE} 100>\mathrm{BDE} 99>\mathrm{BDE} 153$, BDE $154>\mathrm{BDE} 28$, as has been observed previously by others (17); BDE 47, BDE 99, and BDE 100 make up about $90 \%$ on average of the total PBDE load. The same observations were made by Jansson et al., Christensen et al., and Asplund et al. $(18,19,37)$

For some species and locations in this study, this general order was not always observed. Shrimp displayed a deviant profile, with a general order in decreasing concentration of $\operatorname{BDE} 47>\operatorname{BDE} 99>\operatorname{BDE} 153>\operatorname{BDE} 100>\operatorname{BDE} 154>\mathrm{BDE}$ 28 , for both BNS and SE locations. Similarly the profile in bib tissues was different, namely BDE $47>$ BDE $99>$ BDE 100 $>\mathrm{BDE} 153, \mathrm{BDE} 154>\mathrm{BDE} 28$. Figures 3 and 4 show the different profiles of the different species and tissues for BNS and SE, respectively. The observed profile difference for shrimps can be explained by statistically different BDE 99 , BDE 100 , and BDE 153 contributions to the total BDE-load, with mean values of $30=1 \%, 7 \pm 1 \%$ and $11 \pm 1 \%(n=13)$, respectively, while the mean profile contributions of these three congeners for all other species were $10 \pm 0 \%, 16 \pm 0 \%$, 


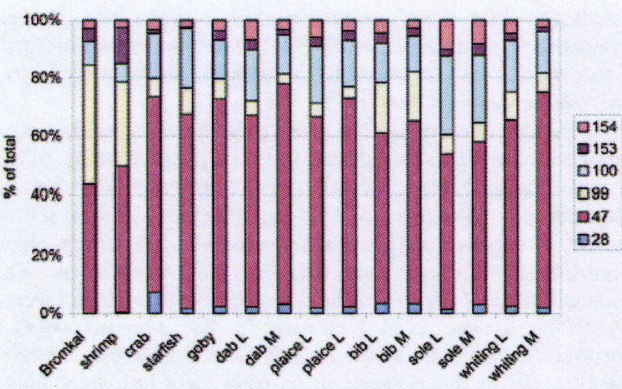

FICURE 3. PBDE Profiles in BNS samples and profile of Bromkal 70-5DE technical mixture. "L" represents liver samples and " $M$ " represents muscle.

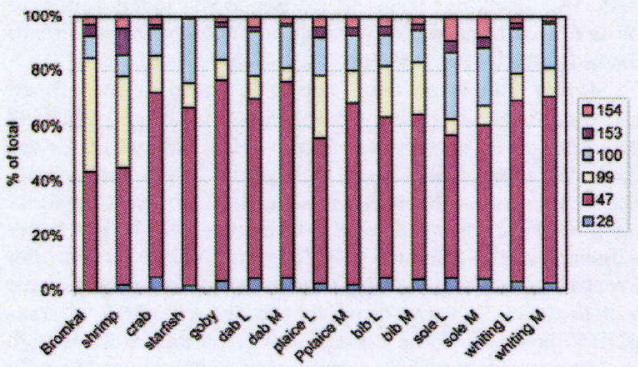

FIGURE 4. PBDE Profiles in SE samples and profile of Bromkal 70-5DE technical mixture. "L" represents liver samples and "M" represents muscle.

and $2 \pm 0 \%(n=130)$, respectively. Additionally, a significantly lower relative BDE 47 concentration was noted, which was on average $45 \pm 3 \%(n=13)$, while the mean for all other locations was $64 \pm 0 \%(n=130)$.

These observations can indicate that metabolization of BDE 99 and 153 is not so well developed in shrimp. These two congeners can both be theoretically metabolized to BDE 47 by debromination processes ( 9 ), which can also explain the relatively low BDE 47 percentage found in the samples with higher BDE 99 and 153 values.

Stapleton et al., who performed a feeding study on common carp (Cyprinus carpio), demonstrated that metabolic debromination from BDE 99 to BDE 47 occurs (29). After administration of food pellets spiked with BDE 99, it could be concluded that accumulation of $\mathrm{BDE} 99$ was minimal and that this congener was very quickly transformed to $B D E$ 47 (40). Dodder et al. also observed the lower BDE 99 concentrations in carp compared to other fish species collected at the same locations (41).

Kierkegaard et al. have also observed extensive metabolization after administration of BDE 209 technical product to rainbow trout (32). BDE 209 could hardly be detected in the tissues, but a wide range of nona- to hexa-congeners, as well as BDE 99, appeared. This observation indicates that the uptake and metabolization of BDE 209 in the samples of the present study cannot be ruled out and that metabolization of this congener may well be a partial reason for the high levels of BDEs encountered in the SE samples.

The present study clearly shows though that BDE 99 can accumulate to a rather high extent depending on which species and locations are selected. This absence or accumulation of BDE 99 can be at least partially explained by metabolic differences between species.

Ratio between BDE 99 and BDE 100. In the present study different ratios between BDE 99 and BDE 100 were observed in the different samples and tissues analyzed. When calculating these ratios, the mean was taken of all samples of 1 species or tissue from BNS and SE and the calculated ratios were rounded off to the nearest integer. Several other studies also made interesting observations concerning the ratio between BDE 99 and BDE $100(37,42)$.

In the present study, similar ratios were observed for starlish, goby, and whiting; the ratios were statistically different when comparing BNS and SE locations (30:70 and $60: 40$, for BNS and SE, respectively). Sole, dab, and plaice displayed a comparable BDE 99:BDE 100 ratio of 20:80 for the BNS locations, but ratios were not the same for the three species when looking at the SE samples $(20: 80,30: 70$, and $60: 40$, respectively). Bib and shrimp showed completely different ratios, with respectively 55:45 and 80:20 for BNS locations, while for SE locations, these ratios were 60:40 and 80:20, respectively. All ratios are presented in Table 5.

The statement made earlier by Christensen et al. that the mean BDE 99:BDE 100 ratio in marine environmental locations which are not excessively polluted, is equal to 30 : 70 , is not a general fact (37). In this study, four distinct ratiogroups were found for different species from the same locations (BNS), namely 30:70, 20:80, 55:45, and 80:20. For SE locations, the calculated ratios were $60: 40,40: 60,30: 70$, 20:80, and 80:20. We hereby conclude that the BDE 99:BDE 100 ratio is clearly species- and location-dependent. Tissue dependence (liver-muscle) could not be demonstrated for this $\mathrm{BDE} 99: \mathrm{BDE} 100$ ratio.

A difference in the BDE 99:BDE 100 ratio for a specific species was observed between BNS and SE locations, which is probably related to higher PBDE concentrations in the SE area $(10-30$-fold increase). This difference was statistically significant for crab and plaice; for the BNS, the ratios were $30: 70$ and 20:80, respectively, while for the SE, both ratios were 60:40. Minor changes were found for starfish, goby, and whiting $(30: 70 \rightarrow 40: 60)$ and for dab $(20: 80 \rightarrow 30: 70)$, but these changes were not statistically significant. No profile change could be observed for shrimp and sole samples, which were constant for BNS and SE with $80: 20$ and 20:80, respectively.

The link between these changes in BDE 99:BDE 100 ratios, which can also be expressed as a relative increase of BDE 99 , is most probably due to an increased exposure to this congener. The commercial product Bromkal 70-5DE showed a BDE 99:BDE 100 ratio of $84: 16$ (43). In sediments from the SE, which were analyzed in the BROC feasibility study, this ratio was found to be $80: 20$ (25). The BDE 99:BDE 100 ratio found for shrimp (80:20) is very similar to the ratio for the Bromkal technical mixture and virtually identical to the ratio found in SE sediment. This ratio does not change between $B N S$ and SE. Shrimp simply reflects the Bromkal and sediment constitution pattern for these congeners, suggesting that the compound is readily bioavailable, but shrimp clearly lacks metabolization capability.

Profile changes, when comparing a species from a nonpolluted area (BNS) to a polluted area (SE), are probably due to complete or partial lack of metabolization capacity. In the case of a changing ratio, the species' metabolism cannot keep up with the constant input of new pollutants and the ratio $\mathrm{BDE} 99: \mathrm{BDE} 100$ increases. If no profile changes can be observed, as for shrimp (ratio 80:20) and sole (ratio 20:80) samples, the species is not able to metabolize and tissue levels reflect the background profile (shrimp), or the metabolic turnover of BDE 99 is of such magnitude that its steadystate BDE profile is maintained (sole). All other species, which present ratios between $80: 20$ and 20:80, have metabolic abilities somewhere between those of shrimp and sole.

Although sole can probably be classified as a high metabolizer, this is maybe not the case for all congeners. 


\begin{tabular}{|c|c|c|c|c|}
\hline sample type & low pollution & high pollution & location & reference \\
\hline $\begin{array}{l}\text { Bromkal 70-5DE } \\
\text { sediment } \\
\text { shrimp } \\
\text { crab } \\
\text { starfish } \\
\text { goby } \\
\text { dab } \\
\text { plaice } \\
\text { bib } \\
\text { sole } \\
\text { whiting } \\
\text { blue mussel } \\
\text { shorthorn sculpin } \\
\text { uvak } \\
\text { starry ray } \\
\text { steelhead trout } \\
\text { steelhead trout } \\
\text { baltic salmon } \\
\text { baltic salmon } \\
\text { salmonids } \\
\text { pike } \\
\text { carp } \\
\text { carp } \\
\text { carp } \\
\text { white crapie } \\
\text { smelt } \\
\text { whale blubber } \\
\text { porpoise blubber } \\
\text { porpoise liver }\end{array}$ & $\begin{array}{l}n a^{b} \\
\text { nab } \\
80: 20 \\
30: 70 \\
30: 70 \\
30: 70 \\
20: 80 \\
20: 80 \\
55: 45 \\
20: 80 \\
30: 70 \\
80: 20 \\
30: 70 \\
30: 70 \\
30: 70 \\
\text { na }^{b} \\
\text { na }^{b} \\
\text { na }^{b} \\
\text { na }^{b} \\
\text { nab }^{b} \\
\text { na }^{b} \\
\text { nab }^{b} \\
\text { na }^{b} \\
\text { nab }^{b} \\
\text { nab }^{b} \\
\text { nab } \\
70: 30 \\
60: 40 \\
50: 50\end{array}$ & $\begin{array}{l}84: 16 \\
80: 20 \\
80: 20 \\
60: 40 \\
40: 60 \\
40: 60 \\
30: 70 \\
60: 40 \\
60: 40 \\
20: 80 \\
40: 60 \\
n a^{b} \\
n a^{b} \\
n a^{b} \\
n a^{b} \\
60: 40 \\
60: 40 \\
60: 40 \\
60: 40 \\
50: 50 \\
80: 20 \\
5: 95 \\
5: 95 \\
0: 100 \\
60: 40 \\
80: 20 \\
n a^{b} \\
\text { nab } \\
\text { nab }\end{array}$ & $\begin{array}{l}\text { nab } \\
\text { Scheldt } \\
\text { BNS - SE } \\
\text { BNS - SE } \\
\text { BNS - SE } \\
\text { BNS - SE } \\
\text { BNS - SE } \\
\text { BNS - SE } \\
\text { BNS - SE } \\
\text { BNS - SE } \\
\text { BNS - SE } \\
\text { Denmark } \\
\text { Southern Greenland } \\
\text { Southern Greenland } \\
\text { Southern Greenland } \\
\text { Lake Michigan } \\
\text { Lake Michigan } \\
\text { Baltic Sea } \\
\text { Baltic Sea } \\
\text { Lake Michigan } \\
\text { Sweden } \\
\text { Hadley Lake (USA) } \\
\text { Belgium } \\
\text { Lab exposure experiments } \\
\text { Hadley Lake (USA) } \\
\text { Lake Ontario (USA) } \\
\text { Faroe Islands (Atlantic) } \\
\text { England and Wales } \\
\text { Belgian North Sea coast }\end{array}$ & $\begin{array}{l}\text { Sjodin et al. (1998) (43) } \\
\text { Lohman et al. }(2003)(25) \\
\text { this study } \\
\text { this study } \\
\text { this study } \\
\text { this study } \\
\text { this study } \\
\text { this study } \\
\text { this study } \\
\text { this study } \\
\text { this study } \\
\text { Christensen et al. (2001) (42) } \\
\text { Christensen at al. (2002) (37) } \\
\text { Christensen et al. (2002) (37 } \\
\text { Christensen et al. (2002) (37) } \\
\text { Asplund et al. (1999) (39) } \\
\text { Asplund et al. (1999) (39) } \\
\text { Asplund et al. (1999) (39) } \\
\text { Asplund et al. (1999) (39) } \\
\text { Manchester-Neesvig et al. (2001) (50) } \\
\text { Sellstrom et al. (1998) (51) } \\
\text { Dodder t al. (2000) (40) } \\
\text { unpublished data Covaci et al. } \\
\text { Stapleton et al. (2003) (41) } \\
\text { Dodder et al. (2000) (40) } \\
\text { Dodder et al. (2000) (40) } \\
\text { Lindstrom et al. (1999) (52) } \\
\text { Law et al. (2002) (53) } \\
\text { Covaci et al. (2002) (54) }\end{array}$ \\
\hline
\end{tabular}

aivision concerning low-high pollution was based on similarity of concentration with levels found in this study (BNS $=$ low, $S E=$ high). ${ }^{b}$ na = not avallable.

BDE 154 contribution to total was found to be statistically higher in sole tissues when compared to all other samples. Relative concentrations of BDE 99 in sole samples are low, as mentioned, which is most probably due to the high metabolic turnover. This lower BDE 99 value can maybe also be related to the higher BDE 154 levels found, since theoretical debromination is possible from $\mathrm{BDE} 154$ to $\mathrm{BDE} 99$. A third possible explanation for this profile observation can be that sole efficiently metabolizes BDE 99 to BDE 47 but can also metabolize BDE 183 to BDE 154, which might explain the high levels of BDE 154. Stapleton et al. has demonstrated the debromination of BDE 183 to BDE 154 by a carp feeding study using food pellets spiked with BDE $183(40)$. BDE 100 can also accumulate to a higher extent due to its smaller molecular size when compared to BDE 99 , since smaller molecular size may allow congeners to bioaccumulate more readily (44).

When looking at all the possible explanations for these profiles, it can be concluded that it is very difficult to draw any conclusions just by looking at tissue levels without taking into regard other parameters, such as metabolization, uptake, molecular size, etc.

Ratio of BDE 99:BDE 100 in Other Studies. The use of the BDE 99:BDE 100 ratio cannot give any information about the pollution of the area, unless this ratio of the same species from a nonpolluted location, combined with knowledge about the metabolization ability of the species, is known. In this study, the same species were sampled at different areas (polluted (SE) vs non polluted (BNS)). The exposure of the organisms at the two areas is not equal, and we can assume that the species uptake ability of PBDEs is not location dependent.

For additional data from different locations and background exposures, different $\mathrm{BDE}$ 99:BDE 100 ratios were calculated in fish, mussels, and marine mammals from similar studies in Europe, North America, and the Arctic (Table 5).
This ratio is dependent on a variety of parameters, such as species, environmental PBDE exposure, environmental profile, and tissue type. The BDE 99:BDE 100 ratio can be useful though, to compare the pollution pattern from different locations.

Marine organisms seem to increase their metabolic capabilities when they climb the evolutionary ladder. The BDE 99:BDE 100 ratios for lower organisms, like mussels and shrimp, tend to be more BDE 99 dominant (80:20), while those for higher organisms, e.g. sole and carp, are more BDE 100 dominant (20:80 and 5:95, respectively, Table 5).

Ikonomou et al. reported that crab was enriched in lower brominated PBDEs (i.e. tri and tetra), whereas sole was enriched in higher brominated PBDEs (i.e. penta and hexa) (3). The same observation can be made in this study (Figures 3 and 4): BDE 28 is significantly higher for erab when compared to sole (only for BNS), whereas BDEs 100 and 154 are significantly higher for sole. Following these findings, it might be necessary to include a benthic invertebrate species such as crab in any work attempting to address PBDE profiles in the environmental biota. because the levels of lower brominated congeners might be improperly assessed using only fish. When fish is used, the metabolic differences should be kept well in mind before drawing any conclusions.

Correlations and Relations. Regression coefficients between concentrations found in SE samples and distance to Antwerp were found to be between $R^{2}=0.58$ and $R^{2}=0.77$ $(p<0.05$; Table 6$)$. These geographical trends were only significant for crab and sole though. This calculation could only be performed on samples for which sufficient analyses had been performed (crab, shrimp, and bib, sole, and whiting as well muscle as liver). Generally, the geographical trend is highly similar for all species, suggesting a rising trend in total PBDE concentration related to one or more point sources situated upstream the Scheldt, as already claimed in other studies (16) 


\begin{tabular}{|c|c|c|c|}
\hline \multicolumn{4}{|c|}{$\begin{array}{l}\text { TABLE 6. Regression between Total PBDEs and Distance to } \\
\text { Antwerp }\end{array}$} \\
\hline & $A^{*}$ & $p$ & $N$ \\
\hline $\begin{array}{l}\text { sole liver } \\
\text { plaice liver } \\
\text { bib liver } \\
\text { whiting liver } \\
\text { sole muscle } \\
\text { bib muscle } \\
\text { whiting muscle } \\
\text { shrimp } \\
\text { crab }\end{array}$ & $\begin{array}{l}0.77 \\
0.12 \\
0.53 \\
0.59 \\
0.68 \\
0.44 \\
0.36 \\
0.52 \\
0.58\end{array}$ & $\begin{array}{l}0.02 \\
0.77 \\
0.10 \\
0.23 \\
0.04 \\
0.15 \\
0.40 \\
0.07 \\
0.05\end{array}$ & $\begin{array}{l}6 \\
3 \\
6 \\
4 \\
6 \\
6 \\
4 \\
7 \\
7\end{array}$ \\
\hline
\end{tabular}

The geographical trend in concentrations for the SE is much less pronounced for fish (Table 6), which can be related to their less sedentary character. This is especially the case for the more migrating nature of the gadoids compared to benthic invertebrates (17). The large tidal movements on the SE probably also play an important role in this nonsignificant regression coefficients (45). For the BNS area, locations 1,4 , 5 , and 9 generally show the lowest concentrations. BDElevels of locations 6,7 , and 8 , which are located in the vicinity of the Zeebrugge harbor, are more elevated than those of the other BNS locations. This increase is only statistically significant for whiting tissues and for benthic invertebrates. For all other samples the increase in concentration is also present but not statistically significant. This rise in PBDE concentrations can possibly be related to industrial and dredging activities in the harbor of Zeebrugge but is more probably due to influence of the discharge plume of the Scheldt into the North Sea, which can reach as far as Ostend (45). From location 10 onward, which can be considered the beginning of the SE, PBDE levels increase very rapidly, going from $1.2 \mathrm{ng} / \mathrm{g}$ ww for crabs at location 10 to $29.9 \mathrm{ng} / \mathrm{g} \mathrm{ww}$ at location 16. For fish liver samples, concentrations up to $984 \mathrm{ng} / \mathrm{g}$ ww were observed for bib, but this is probably related to its high lipid content (approximately 55\%).

No correlation could be observed between lipid pereentage and total PBDE load in the fish samples, nor in starfish or shrimp. This might suggest that for these organisms, the majority of PBDEs is taken up by the diet, and that bioconcentration is of minor importance. For crab samples, however, a regression coeflicient of $R^{2}=0.77(p<0.05)$ was calculated between PBDE load and lipid percentage. This might suggest that for crab, bioconcentration plays a rather important role in the accumulation of these compounds. Flying crabs are scavengers, which makes them difficult organisms to draw conclusions from, since their place in the food web is complex: crab feeds on organisms which are located lower in the food chain as well as on dead fish, which occupy a higher position (35). This might partly explain the rather high concentrations found in crab tissue.

No relation could be found between fish size and contaminant load for the samples from this study. This observation might be explained by the low sample number. as has been shown in other studies (26).

Liver Accunulation. Generally, PBDEs tend to accumulate more in liver than in muscle or adipose tissue (46). Lipid normalized concentrations were used to compensate for the influence of the higher lipid concentration in liver tissue. To express the preferential accumulation of PBDEs, the total concentration in liver was divided by the total concentration in liver and the total concentration in muscle. The obtained ratio can be used as an indicator for preferential accumulation in liver; a ratio of 0.5 means that no preferential accumulation is observed; higher or lower ratios indicate preferential liver or muscle accumulation, respectively. For dab, plaice, bib, and whiting, ratios of $0.57=0.02(n=7)$, $0.55 \pm 0.04(n=8), 0.64 \pm 0.04(n=11)$, and $0.67 \pm 0.03(n$

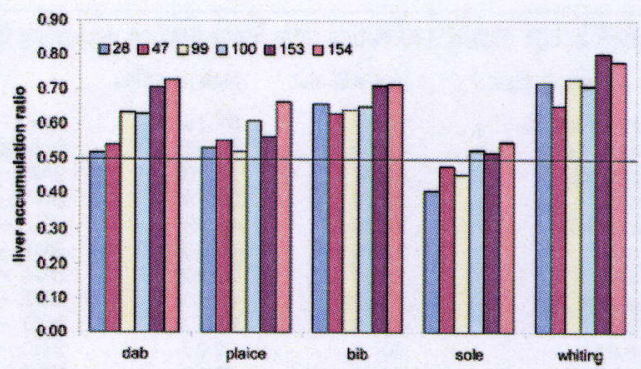

FIGURE 5. Liver accumulation ratio per congener in different fish species; ratios higher than 0.50 indicate preferential liver accumulation. Ratios are higher for higher degree of bromination.

$=10$ ) were found for the sum of PBDEs. A similar ratio was found for whiting by Boon et al., indicating that these species tend to accumulate the targeted PBDE congeners selectively in their liver (17). In the present study, a ratio of $0.47 \pm 0.03$ ( $n=13$ ) was found for sole, however, suggesting no preferential storage of PBDEs in liver. The previously assumed high metabolic capability of sole, which can result in low tissue concentrations, can also be held responsible for this deviant ratio. Too few samples were available to draw any statistically relevant conclusions though.

The selective liver accumulation could be governed by passive distribution, by lipid content, or by an active hepatic accumulation process. Also in pike liver, active enrichment for $\mathrm{BDE} 47$ was observed, which was related to the detoxifying role of the liver in xenobiotic metabolization processes and not. solely to the passive redistribution governed by lipid content (46).

In the present study, liver accumulation could not be related to the liver lipid content, which indicates active enrichment could be more likely. Passive accumulation might be an important element for the higher brominated congeners, whereas it has been proposed by Kierkegaard et al. that higher brominated congeners might display a higher liver accumulation due to a higher $\log K_{\mathrm{ow}}$ value in combination with their larger molecular size, which hinders their ability to cross membranes (32). In the present study, higher brominated congeners also showed higher liver accumulation (Figure 5). This higher liver accumulation was only statistically significant for dab, plaice, and sole; $R^{2}$ calculated between degree of bromination and liver accumulation were 0.94 , 0.90 , and $0.92(p>0.05)$, respectively. For bib and whiting, a trend could be observed but was not statistically significant. These observations might suggest that tissue dependent accumulation might well be related to animal species as well as to compound characteristics.

Profile differences could also be observed between muscle and liver, e.g. BDE 47 contribution was significantly lower in liver than in muscle. No possible explanation could be found for this observation.

Bioaccumulation/Biomagnification. PBDEs have been shown to biomagnify in the marine environment $(2,17.47)$. Some studies showed that biomagnification of BDE 47,99 . and 100 are approximately equal, whereas reduced biomagnification was observed for BDE 154 (47). This might offer a partial explanation for the relative lack of BDE 154 and abundance of BDE 47 observed in biota profiles when compared to the expected source composition made up of commercial mixtures (Figures 3 and 4). An explanation should also be looked for in the metabolic potential to reduce BDE 154 levels and to form BDE 47 and other congeners. Results from this study might suggest that profiles observed in tissues are only partially related to uptake and background pollution. A large influence on profile can be due to metabolic processes. 


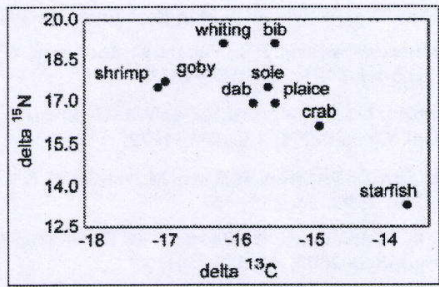

FIGURE 6. Isotopic ratios of ${ }^{13} \mathrm{C}$ and ${ }^{15} \mathrm{~N}$ for the different species of the present study (49).

The major biomagnification step in the food chain occurs from lish to marine mammals (17). Also in lower levels of the food web, from copepods over planktivorous fish to predatory fish, biomagnification was found for tetra- to hexa-PBDEs (36). In the present study, no clear trend could be discovered that would suggest any biomagnification from benthic organisms to fish. All fish species in this study feed on benthic invertebrates (48) and goby, as the latter could be readily encountered in the fish' stomachs.

The use of naturally occurring stable isotopes of carbon and nitrogen can provide more accurate information on food web positioning of marine organisms (49). The carbon and nitrogen isotope ratios $\left({ }^{13} \mathrm{C} / /^{12} \mathrm{C}\right.$ and $\left.{ }^{15} \mathrm{~N} /{ }^{14} \mathrm{~N}\right)$ in an organism reflect those of its diet with a slight selective retention of the heavier isotope and excretion of the lighter one (48). These isotope ratio determinations have not been performed on the samples of the present study, but ratios of the same organisms from the same locations were available in the literature and are graphically presented in Figure 6(48). Based on these data, Asterias rubens is positioned at the base of the food chain sampled in the present study. The benthic invertebrate species Crangon crangon displays a rather high food web positioning based on the isotope ratios, which can be explained by its onnivorous and scavenging feeding pattern. Gadoids display the highest food web position encountered in this study. This is also related to their carnivorous feeding pattern. These lood web positioning differences are not reflected in the measured PBDE concentrations in the different species of the present study.

\section{Acknowledgments}

The authors thank the VLIZ for their logistic assistance and Dr. A. Cattrijsse for his help with the sampling and species determination on board the ship. We also thank the entire crew of Zeeleeuw for taking us back safely to the harbor despite the harsh weather conditions. Johan Maervoet and Dr. Shaogang Chu are also acknowledged for their assistance during sampling and dissection. The authors are also gratefu. to Cambridge Isotope Laboratories, who kindly provided the ${ }^{13} \mathrm{C}-\mathrm{BDE} 209$ standard solution.

\section{Supporting Information Available}

Detailed statistical descriptors (range, median, $N$ ) of all benthic invertebrate samples and goby from all locations (Table SI-1) and these statistical descriptors for all fish samples from BNS (Table SI-2) and SE (Table SI-3). This material is available free of charge via the Internet at htp:// pubs.acs.org

\section{Note Added after ASAP Posting}

This paper was released ASAP on 09/06/2003 with an incorrect relerence citation in the Ration between BDE 99 and BDE 100 section under Results and Discussion. A sentence was also missing from the Acknowledgments. The correct version was posted $09 / 10 / 2003$

\section{Literature Cited}

(1) de Boer, J.; Allchin, C. Organohalogen Compd. 2001, 52, 13-

(2) de Wil C. A. Chemosphere 2002, 46, 583-624

(3) Ikonomou, M.; Rayne, S.; Fischer, M.; Fernandez, M.; Cremey W. Chemosphere 2002, 46, 649-663.

(4) Strandberg, B.: Dodder, N. G.; Basu, I.; Hites, R. A. Environ. Sci. Technol. 2001, 35, 1072-1077.

(5) Renner, R. Environ. Sci. Technol. 2000, 34, 222A-226A.

(6) World Health Organization. Environmental Health Criteria 162: Brominated diphenyl ethers; Geneva, Swizzerland, 1994.

(7) de Boer. J.; de Boer, K.; Boon, J. P. In The Handbook of Environmental Chemistry, New Types of Persistent Halogenated Compounds; Paasivirta, J., Ed.; Springer-Verlag: 2000; pp 6195, ISBN 3-540-6583-6.

(8) Bromine Science and Environmental Forum (BSEF). Major Brominated flame retardants volume estimates; Brussels, Belgium, 2003.

(9) Darnerud, P. O.; Eriksen, G. S.; Jóhannesson, T.; Larsen, P. B.; Viluksela, M. Environ. Health Perspect. 2001, 109, 49-68.

(10) Bromine Science and Environmental Forum (BSEF). An introduction to brominated flame retardants; Brussels. Belgium. 2000.

(11) Bergman. $\AA$. Organohalogen Compd. 2000, 47, 36-40.

(12) McDonald, T. A. Chemosphere 2002, 46, 745-755.

(13) Gustafsson, K.; Björk, M.; Burreau, S.; Gilek, M. Environ. Toxicol. Chem. 1999, 18, 1218-1224.

(14) Norén, K.; Meironyté, D. Chemosphere 2000, 40, 1111123.

(15) Hale, R. C. La Guardia, M. J. Harvey, E. P.: Matteson. M.: Duff, W. H.; Gaylor, M. O. Environ. Sci. Technol. 2001, 35, 4585-4591.

(16) de Boer, J.; Wester, P. G.; van der Horst, A.; Leonards, P. E. G. Environ. Pollut. 2003, 122, 63-74.

(17) Boon, J. P. Lewis, W. E. Tjoen-A-Choy, M. R.; Allchin, C. R.; Law, R. J.; de Boer, J.; Ten Hallers-Tjabbes, C. C.; Zegers, B. N. Environ. Sci. Technol. 2002, 36, 4025-4032.

(18) Allchin, C.; Law, R.; Morris, S. Environ. Pollut. 1999, 105, 197207.

(19) Jansson, B.; Asplund, L.; Olsson, M. Chemosphere 1987, 16, 23432349.

(20) Sellström, U.; Jansson, B.; Kierkegaard, A.; de Wit, C.; Odsjö, T.; Olsson. M. Chemosphere 1993, 26, 1703-1718.

(21) de Boer, J. Chemosphere 1989, 18, 2131-2140.

(22) Jacobs, M. N.; Covaci. A.; Schepens. P. Environ. Sci. Technol. 2002, 36, 2797-2805.

(23) de Boer, J.; Colino. W. P. Chemosphere 2002, 46, 625-633.

(24) de Boer, J.; Wells, D. E.; Norén, K. Organohalogen Compd. 2002, $58,197-200$.

(25) Lohruan, M.; van Leeuwen, S.; de Boer, J. Draft report on the feasability of certification of BFRs in sediment - BROC Project; Rivo, The Netherlands, 2003.

(26) Larsson, P.; Okla, L.; Collvin, L. Environ. Toxicol. Chem. 1993, $12,855-861$

(27) Kozlova, T. A. J. Fish. Biol. 1997, 50, 734-743.

(28) Hislop, J. R. G.; Harris, M. P.; Smith. J. G. M. J. Zool. 1991, 224, $501-517$.

(29) Stapleton, H. M.; Letcher, R. J.; Baker, J. E. Organohalogen Compd. 2002, 58, 201-204.

(30) Sjödin, A. Occupational and dietary exposure to Organohalogen substances, with special emphasis on polybrominated diphenyl ethers, Ph.D. Thesis, University of Slockholm, Sweden, 2000.

(31) Lepom, P.; Karasyova, T.; Sawal, G. Organohalogen Compd. 2002, $58,209-212$.

(32) Kierkegaard, A.; Balk, L.; Tjürnlund, U.; de Wit, C.; Jansson, B. Environ Sci. Technol. 1999, 33, 1612-1617

(33) Sellström, U.; Lindberg, P.; Häggberg, L.; de Wit. C. Proceedings of the second international workshop on brominated tlame retardants, 2001; pp 159-162.

(34) Sjödin, A.; Hagmar, L; Klasson-Wehler, E.; Kronholm-Diab, K. Jakobsson, E.; Bergman, A. Environ. Health Perspect. 1999, 107, 643-648.

(35) Groenewold, S.; Fonds, M. ICES J. Mar. Sci. 2000. 57, 13951406.

(36) Burreau, S.; Zebühr, I.; Ishaq, R.; Broman, D. Organohalogen Compd. 2000, 47, 253-255.

(37) Christensen, J. H.; Glasius, M.; Pécseli, M.; Platz. J.; Pritzl, G. Cherrosphere $2002,47,631-638$

(38) de Boer, J.; van der Zande. T. E.; Pieters, H.; Ariese, F.; Schipper, C. A.; van Brummelen, T.; Vethaak, D. J. Environ. Monit. 2001 , 3, 386-393.

(39) Asplund, L.; Hornung, M.; Peterson, R. E.; Thuresson, K. Bergman, $\AA$. Organohalogen Compd. 1999, 40, 351-354. 
(40) Stapleton, H. M. Assimilation and metabolism of polybrominted diphenyl ethers by the common carp, Cyprinus carpio, Ph.D. Thesis. Universiry of Maryland. United States, 2003.

(41) Dodder, N. G.; Strandberg, B.; Hites, R. A. Environ. Sci. Technol. 2002, 36, 146-151

(42) Christensen. J. H.; Platz, J. J. Environ. Monitor. 2001, 3, 543547.

(43) Sjödin, A.; Jakobsson, E; Kierkegaard, A.; Marsh, G.; Sellström. U. J. Cromatogr. A 1998, 822, 83-89.

(44) Luross, J. M.; Alaee, M.; Sergeant, D. B.; Cannon, C. M.; Whittle, D. M.; Solomon, K. R.; Muir, D. C. G. Chemosphere 2002, 46, $665-672$.

(45) Delhez, E. J. M.; Carabin, G. Estuar. Coast. Shelf. S. 2001, 53, 477-491.

(46) Burreau, S.; Broman, D.; Örn, U. Chemosphere 2000, 40, 97785.

(47) Burreau, S.; Broman, D.; Zebühr, Y. Organohalogen Compd. $1999,40,363-366$

(48) Das, K. Trace metal contamination and detoxication processes in marine mammals from European coasts, Ph.D. Thesis, Université de Liège, Belgium, 2002.
(49) Hobson, K. A.; Welch, H. E. Mar. Ecol. Prog. Ser. 1992, 84, 9-18.

(50) Manchester-Neesvig, J. B.; Valters, K.; Sonzogni, W. C. Environ. Sci. Technol. 2001, 35, 1072-1077.

(51) Sellström, U.; Kierkegaard, A.; de Wit, C.; Jansson, B. Environ. Toxicol. Chem. 1998, 17, 1065-1072.

(52) Lindström, G.; Wingfors, H.; Dam, M.; van Bavel, B. Arch. Environ. Con. Tox. 1999, 36, 355-363.

(53) Law, R. J.; Allchin, C. R.; Bennett, M. E.; Morris, S.; Rogan, E. Chemosphere 2002, 46, 673-681.

(54) Covaci, A.; Van de Vijver, K.; De Coen, W.; Das, K.; Bouquegnean, J. M.; Blust, R.; Schepens, P. Mar. Pollut. Bull. 2002, 44, 11571165.

Received for review May 19, 2003. Revised manuscript received June 25, 2003. Accepted July 24, 2003.

ESO34503R 
TABLE SI-1. Statistical descriptors from BNS and SE samples: shrimp, crab, starfish, and goby. Concentrations are expressed as ng/g ww

\begin{tabular}{|c|c|c|c|c|c|c|c|c|}
\hline \multirow{4}{*}{$\begin{array}{c}\text { shrimp } \\
\text { BNS }\end{array}$} & & BDE 28 & BDE 47 & BDE 100 & BDE 99 & BDE 154 & BDE 153 & $\Sigma$ PBDEs \\
\hline & Range & n.d & $0.01-0.03$ & n.d. -0.01 & $0.01-0.02$ & n.d. & n.d. -0.01 & $0.02-0.08$ \\
\hline & Median & n.d. & 0.02 & n.d. & 0.01 & n.d. & 0.01 & 0.03 \\
\hline & $\mathrm{N}$ & 5 & 5 & 5 & 5 & 5 & 5 & 5 \\
\hline \multirow{3}{*}{$\begin{array}{l}\text { crab } \\
\text { BNS }\end{array}$} & Range & $0.01-0.11$ & $0.25-0.96$ & $0.05-0.24$ & $0.02-0.09$ & $0.02-0.06$ & $0.01-0.02$ & $0.36-1.4$ \\
\hline & Median & 0.05 & 0.57 & 0.12 & 0.06 & 0.03 & 0.01 & 0.94 \\
\hline & $\mathrm{N}$ & 7 & 7 & 7 & 7 & 7 & 7 & 7 \\
\hline \multirow{3}{*}{$\begin{array}{c}\text { starfish } \\
\text { BNS }\end{array}$} & Range & n.d. -0.03 & $0.07-0.94$ & $0.04-0.26$ & $0.01-0.23$ & $0.01-0.02$ & n.d. & $0.14-1.5$ \\
\hline & Median & 0.01 & 0.41 & 0.14 & 0.03 & 0.01 & n.d. & 0.59 \\
\hline & $\mathrm{N}$ & 7 & 7 & 7 & 7 & 7 & 7 & 7 \\
\hline \multirow{3}{*}{$\begin{array}{l}\text { goby } \\
\text { BNS }\end{array}$} & Range & $0.01-0.04$ & $0.11-1.3$ & $0.02-0.23$ & $0.01-0.12$ & $0.01-0.06$ & $0.01-0.06$ & $0.16-1.8$ \\
\hline & Median & 0.02 & 0.45 & 0.08 & 0.05 & 0.02 & 0.02 & 0.66 \\
\hline & $\mathrm{N}$ & 6 & 6 & 6 & 6 & 6 & 6 & 6 \\
\hline \multirow{3}{*}{$\begin{array}{c}\text { shrimp } \\
\text { SE }\end{array}$} & Range & n.d. -0.16 & $0.07-4.0$ & $0.01-0.66$ & $0.06-3.1$ & $0.01-0.40$ & $0.01-0.88$ & $0.20-8.3$ \\
\hline & Median & 0.03 & 0.68 & 0.10 & 0.50 & 0.07 & 0.18 & 1.6 \\
\hline & $\mathrm{N}$ & 8 & 8 & 8 & 8 & 8 & 8 & 8 \\
\hline \multirow{3}{*}{$\begin{array}{c}\text { crab } \\
\text { SE }\end{array}$} & Range & $0.09-1.4$ & $0.76-20.2$ & $0.20-3.2$ & $0.06-4.9$ & $0.03-1.0$ & $0.01-0.46$ & $1.8-29.9$ \\
\hline & Median & 0.68 & 8.9 & 1.2 & 1.6 & 0.37 & 0.19 & 13.6 \\
\hline & $\mathrm{N}$ & 7 & 7 & 7 & 7 & 7 & 7 & 7 \\
\hline \multirow{3}{*}{$\begin{array}{c}\text { starfish } \\
\text { SE }\end{array}$} & Range & 0.28 & 9.6 & 3.2 & 2.2 & 0.19 & 0.01 & $1.6-15.5$ \\
\hline & Median & n.a. & n.a. & n.a. & n.a. & n.a. & n.a. & n.a. \\
\hline & $\mathrm{N}$ & 1 & 1 & 1 & 1 & 1 & 1 & 1 \\
\hline \multirow{3}{*}{$\begin{array}{l}\text { goby } \\
\text { SE }\end{array}$} & Range & $0.11-0.34$ & $2.8-7.1$ & $0.55-1.2$ & $0.21-0.73$ & $0.12-0.22$ & $0.10-0.19$ & $3.9-9.7$ \\
\hline & Median & 0.23 & 4.9 & 0.86 & 0.47 & 0.17 & 0.14 & 6.8 \\
\hline & $\mathrm{N}$ & 2 & 2 & 2 & 2 & 2 & 2 & 2 \\
\hline
\end{tabular}

n.a. = not available; n.d. = not detected; BNS = Belgian North Sea SE = Scheldt Estuary 
TABLE SI-2. Statistical descriptors of fish data from BNS samples. Concentrations are expressed as $\mathbf{n g} / \mathrm{g}$ ww

\begin{tabular}{|c|c|c|c|c|c|c|c|c|}
\hline & & BDE 28 & BDE 47 & BDE 100 & BDE 99 & BDE 154 & BDE 153 & ¿PBDES \\
\hline \multirow{3}{*}{ dab L } & Range & $0.07-0.28$ & $1.9-8.3$ & $0.50-2.1$ & $0.14-0.59$ & $0.18-0.69$ & $0.03-0.37$ & $2.8-12.0$ \\
\hline & Median & 0.14 & 4.3 & 1.1 & 0.33 & 0.50 & 0.27 & 6.8 \\
\hline & $\mathrm{N}$ & 6 & 6 & 6 & 6 & 6 & 6 & 6 \\
\hline \multirow{3}{*}{ dab $M$} & Range & n.d. -0.03 & $0.08-0.30$ & $0.02-0.05$ & n.d. -0.03 & n.d.- 0.01 & n.d. -0.01 & $0.11-0.41$ \\
\hline & Median & 0.01 & 0.23 & 0.04 & 0.01 & 0.01 & 0.01 & 0.32 \\
\hline & $\mathrm{N}$ & 6 & 6 & 6 & 6 & 6 & 6 & 6 \\
\hline \multirow{3}{*}{ plaice L } & Range & $0.02-0.15$ & $2.3-3.8$ & $0.50-1.1$ & $0.05-0.40$ & $0.16-0.35$ & $0.06-0.28$ & $3.1-6.0$ \\
\hline & Median & 0.09 & 2.9 & 1.0 & 0.22 & 0.27 & 0.11 & 4.4 \\
\hline & $\mathrm{N}$ & 5 & 5 & 5 & 5 & 5 & 5 & 5 \\
\hline \multirow{3}{*}{ plaice $\mathbf{M}$} & Range & n.d.-0.01 & $0.04-0.31$ & $0.01-0.07$ & n.d.- 0.03 & n.d.- 0.02 & n.d. -0.02 & $0.06-0.47$ \\
\hline & Median & 0.01 & 0.12 & 0.03 & 0.01 & 0.01 & 0.01 & 0.19 \\
\hline & $\mathrm{N}$ & 6 & 6 & 6 & 6 & 6 & 6 & 6 \\
\hline \multirow{3}{*}{ bib L } & Range & $0.81-4.5$ & $10.3-75.6$ & $3.3-17.1$ & $4.1-20.3$ & $1.4-5.0$ & $1.1-3.5$ & $21.0-122$ \\
\hline & Median & 2.5 & 55.5 & 10.9 & 7.9 & 3.7 & 1.7 & 97.2 \\
\hline & $\mathrm{N}$ & 5 & 5 & 5 & 5 & 5 & 5 & 5 \\
\hline \multirow{3}{*}{ bib M } & Range & n.d. -0.03 & $0.08-0.49$ & $0.02-0.13$ & $0.02-0.08$ & $0.01-0.03$ & $0.01-0.01$ & $0.13-0.76$ \\
\hline & Median & 0.01 & 0.24 & 0.04 & 0.06 & 0.01 & 0.01 & 0.38 \\
\hline & $\mathrm{N}$ & 5 & 5 & 5 & 5 & 5 & 5 & 5 \\
\hline \multirow{3}{*}{ sole L } & Range & n.d. -0.22 & $0.39-3.7$ & $0.26-2.5$ & $0.02-0.77$ & $0.09-0.78$ & n.d.- -0.34 & $0.84-8.2$ \\
\hline & Median & 0.02 & 1.5 & 0.71 & 0.11 & 0.27 & 0.02 & 2.6 \\
\hline & $\mathrm{N}$ & 7 & 7 & 7 & 7 & 7 & 7 & 7 \\
\hline \multirow{3}{*}{ sole $\mathrm{M}$} & Range & n.d.-0.02 & $0.04-0.34$ & $0.02-0.017$ & n.d. -0.09 & $0.01-0.07$ & n.d.- -0.03 & $0.08-0.73$ \\
\hline & Median & 0.01 & 0.21 & 0.11 & 0.03 & 0.03 & 0.02 & 0.4 \\
\hline & $\mathrm{N}$ & 7 & 7 & 7 & 7 & 7 & 7 & 7 \\
\hline \multirow{3}{*}{ whiting L } & Range & $0.42-2.8$ & $11.1-62.8$ & $2.86-16.2$ & $1.6-14.5$ & $1.2-4.1$ & $0.43-2.8$ & $19.7-89.9$ \\
\hline & Median & 0.64 & 16.2 & 4.8 & 2.9 & 1.4 & 0.79 & 25.7 \\
\hline & $\mathrm{N}$ & 6 & 6 & 6 & 6 & 6 & 6 & 6 \\
\hline \multirow{3}{*}{ whiting $\mathrm{M}$} & Range & n.d.- 0.02 & $0.05-0.68$ & $0.01-0.15$ & n.d.- 0.05 & n.d. -0.02 & n.d. -0.01 & $0.07-0.92$ \\
\hline & Median & 0.01 & 0.22 & 0.05 & 0.02 & 0.01 & n.d. & 0.33 \\
\hline & $\mathrm{N}$ & 6 & 6 & 6 & 6 & 6 & 6 & 6 \\
\hline
\end{tabular}

n.a. $=$ not available; $n$.d. $=$ not detected $\mathrm{L}=$ liver; $\mathrm{M}=$ muscle 
TABLE SI-3. Statistical descriptors of fish data from SE samples. Concentrations are expressed as ng/g ww

\begin{tabular}{|c|c|c|c|c|c|c|c|c|}
\hline 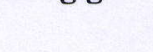 & & BDE 28 & BDE 47 & BDE 100 & BDE 99 & BDE 154 & BDE 153 & ¿PBDEs \\
\hline \multirow{3}{*}{ dab L } & Range & 0.80 & 12.2 & 3.0 & 1.5 & 0.76 & 0.30 & 18.6 \\
\hline & Median & n.a. & n.a. & n.a. & n.a. & n.a. & n.a. & n.a. \\
\hline & $N$ & 1 & 1. & 1. & 1 & 1 & 1 & 1 \\
\hline \multirow{3}{*}{ dab $M$} & Range & 0.03 & 0.47 & 0.10 & 0.03 & 0.02 & 0.01 & 0.66 \\
\hline & Median & n.a. & n.a. & n.a. & n.a. & n.a. & n.a. & n.a. \\
\hline & $\mathrm{N}$ & 1. & 1. & 1 & 1 & 1 & 1 & 1 \\
\hline \multirow{3}{*}{ plaice $\mathrm{L}$} & Range & $2.0-6.5$ & $36.5-186$ & $10.6-40.3$ & $20.2-38.5$ & $2.2-17.7$ & $2.9-15.0$ & 74.4-304 \\
\hline & Median & 2.4 & 47.0 & 13.1 & 25.7 & 2.6 & 3.5 & 94.3 \\
\hline & $\mathrm{N}$ & 3 & 3 & 3 & 3 & 3. & 3 & 3. \\
\hline \multirow{3}{*}{ plaice $\mathbf{M}$} & Range & 0.11 & 4.1 & 0.79 & 0.71 & 0.26 & 0.18 & 6.1 \\
\hline & Median & n.a. & n.a. & n.a. & n.a. & n.a. & n.a. & n.a. \\
\hline & $\mathrm{N}$ & 1. & 1. & 1 & 1. & 1 & 1. & 1 \\
\hline \multirow{3}{*}{ bib L } & Range & $8.5-47.7$ & $107-544$ & $17.5-110$ & $30.3-199$ & $5.5-38.5$ & $5.5-45.2$ & 174-984 \\
\hline & Median & 16.2 & 230 & 46.7 & 69.3 & 15.5 & 13.5 & 392 \\
\hline & $\mathrm{N}$ & 6 & 6 & 6 & 6 & 6 & 6 & 6 \\
\hline \multirow{3}{*}{ bib M } & Range & $0.03-0.27$ & $0.47-3.2$ & $0.09-0.71$ & $0.15-1.1$ & $0.02-0.19$ & $0.02-0.16$ & $0.78-5.6$ \\
\hline & Median & 0.05 & 0.88 & 0.16 & 0.25 & 0.04 & 0.03 & 1.4 \\
\hline & $\mathrm{N}$ & 6 & 6 & 6 & 6 & 6 & 6 & 6 \\
\hline \multirow{3}{*}{ sole L } & Range & $0.63-6.1$ & $8.3-47.7$ & $3.9-26.7$ & $0.61-7.7$ & $1.3-8.7$ & $0.30-7.3$ & $15.0-93.3$ \\
\hline & Median & 1.9 & 26.8 & 11.4 & 3.0 & 4.6 & 1.8 & 49.8 \\
\hline & $\mathrm{N}$ & 6. & 6. & 6 & 6. & 6 & 6 & 6 \\
\hline \multirow{3}{*}{ sole $\mathrm{M}$} & Range & n.d. -0.42 & $0.05-3.9$ & $0.01-1.5$ & n.d.- 0.76 & $0.01-0.58$ & n.d. -0.42 & $0.08-6.9$ \\
\hline & Median & 0.21 & 3.2 & 1.2 & 0.38 & 0.46 & 0.19 & 5.8 \\
\hline & $\mathrm{N}$ & 6 & 6 & 6 & 6 & 6 & 6 & 6 \\
\hline \multirow{3}{*}{ whiting L } & Range & $1.8-10.2$ & $50.6-254$ & $15.9-76.6$ & $4.6-31.3$ & $1.8-8.9$ & $0.46-8.6$ & $75.2-393$ \\
\hline & Median & 8.9 & 169 & 39.1 & 25.4 & 7.1 & 5.1 & 258 \\
\hline & $\mathrm{N}$ & 4. & 4 & 4 & 4 & 4 & 4 & 4. \\
\hline \multirow{3}{*}{ whiting $\mathbf{M}$} & Range & $0.02-0.10$ & $0.72-1.93$ & $0.16-0.45$ & $0.03-0.44$ & $0.02-0.06$ & n.d. -0.05 & $1.0-3.0$ \\
\hline & Median & 0.04 & 1.2 & 0.31 & 0.13 & 0.03 & 0.01 & 1.7 \\
\hline & $\mathrm{N}$ & 4 & 4 & 4 & 4 & 4 & 4 & 4 \\
\hline
\end{tabular}

n.a. $=$ not available; n.d. $=$ not detected $; \mathrm{L}=$ liver $\mathbf{M}=$ muscle 